\title{
DEMOCRACY AND POPULISM: FRIEND OR FOE? A REVIEW OF CAS MUDDE AND CRISTÓBAL ROVIRA KALTWASSER (EDS.) POPULISM IN EUROPE AND THE AMERICAS. THREAT OR CORRECTIVE FOR DEMOCRACY? (CAMBRIDGE UNIVERSITY PRESS, 2012)
}

\author{
JULIANNA FALUDI ${ }^{1}$
}

As commonly expressed, populism is a synonym of demagogy, or an adjective used to describe and criticize the set of tools of a political movement. The meaning of democracy as constructed by language users is dynamically-changing and contextually bound. The interpretation of these two concepts is even more confused from a historical perspective as both the words democracy and populism have served to indicate a range of (in some cases diverging) phenomena, although they are perceived as being from the same semantic and contextual family.

The two editors, Cas Mudde and Cristobal Rovira Kaltwasser, meet the challenge of understanding the relationship of populism and democracy through a comparative analysis that was carried out during an ambitious project. By covering three continents, they draw on a series of contrasting examples plucked from the classic North-South and East-West narrative dimensions. To describe this colorful array of political systems they develop minimum definitions for democracy and populism and arrange them in a unified theoretical framework that is ready to be applied. The very first chapter thus arranges the fifty interpretations of the two notions and provides a toolkit and a set of hypotheses for the empirical analysis that is later explored and tested using a non-representative clutch of examples. The compilation of case studies that is written by several scholars is presented in the second part of the

1 Julianna Faludi is a Ph.D. candidate at the Sociology Program of the Corvinus University of Budapest and Local Development and Global Dynamics Program of the University of Trento; e-mail:faludisociology@gmail.com 
volume and is concluded with a concise study that draws on the findings of the cases developed by the two editors.

In admitting the perplexing variety of phenomena described by the two terms, the first chapter kicks off by elaborating a stripped down definition of populism and democracy. The core attribute of populism is that it divides society into two homogenous and antagonistic groups: 'pure people' and the 'corrupt elite', when politics allegedly acts in favor of a general will (volonté general). The two groups are created through reference to morality where the meanings of 'pure' and sinful (or 'corrupted') are constructed by the populists who are acting in a given social and political context.

Populism has polarized meanings and a strong or weak effect on the quality of democracy depending on the power dynamics it operates within: whether in opposition, or as a governmental force. In history, populism wears different coats: it might appear as a movement, a political style or a discourse, depending on how it strives to articulate the views of the 'mute masses' as the 'voice of people', either ignoring the interests of minorities or even targeting their limitations.

Democracy stripped of its adjectives serves as a term for a combination of popular sovereignty and majority rule (which is supported by populism, in theory). The terms liberal (illiberal) and direct (indirect) democracy have distinct meanings. In the common discourse about democracy one may refer to liberal democracy, as framed by Robert Dahl (omitting the adjective liberal). The common interpretation of liberal democracy is that it is based on the existence of institutions of freedom and rights, in the form of 'institutional guarantees' or institutions of checks and balances (freedom to form and join organizations, freedom of expression, the right to vote, the right of political leaders to compete for votes, eligibility for public office, alternative sources of information, free and fair elections, institutions for making government policies dependent on votes and other expressions of preference). Furthermore, liberal democracy is characterized by the constitutional protection of minority rights along with majority rule.

To measure the quality of a democracy, the volume applies a threedimensional model developed by Diamond and Morlino (deriving from Dahl's concepts), based on the evaluation of the democratic process (do citizens have the power to evaluate whether the government respects the democratic process?), the content (the extent of liberty and political equality), and the result (the existence of a widely-legitimized regime that satisfies citizen's expectations about governance).

Populism affects the quality of democracy both in positive and negative ways depending on its position within the power structure (either in opposition 
or governance) and the society it addresses. Populism's effects are also weakened or reinforced by the level of institutionalization of a democracy (consolidated or unconsolidated). In sum, populism, claim the editors, can be both a corrective and threat to democracy. Rather than relying on theoretical speculations, Mudde and Rovira Kaltwasser derive seven hypotheses about the conditions that influence the strength and type of the impact of populism and test them empirically. As a result, a range of hypotheses are ultimately justified by the findings of the case studies presented in the second part of the book.

The case studies have a wide geographic spread while chronologically they encompass the nineties (embracing the eighties, and the events of the first decade of the new century). What makes this temporal and spatial approach particularly valuable is that it involves a peculiar time of transition that lead various democracies, nested into their different contexts, to a crossroads. The last decade of the $20^{\text {th }}$ Century was characterized by political disillusion, market liberalization, political and economic transition in Eastern and Central-Eastern Europe and the crisis in Latin America. The volume relies on the interaction of the individual case studies, framing them into a unified discourse.

Despite the limitations imposed by the concentration on different geographical loci that make the findings of the analyses context-bound, the case studies draw on regional characteristics in order to identify generalizable findings. Illustrations range from consolidated democracy to populism in opposition: Vlaams Blok (VB) Belgium (91-), the Reform Party of Canada (1987-2000); populism in government FPÖ/BZÖ Austria (2000-2007), Hugo Chávez Venezuela (1998-); unconsolidated democracy, populism in opposition SPR-RSČ Czech Republic (1992-98), Andrés Manuel López Obrador Mexico (2006); and populism in government: Alberto Fujimori Peru (1990-2000), Vladimir Mečiar Slovakia (1992-98).

The content concerning people within the two-dimensional distinction of the 'corrupt elite' and the 'pure people' of populism varies along geographical dimensions. In a set of examples from Europe (Austria, Belgium, Czech Republic, Slovakia) populism exploits social tension by defining the division between the elite and the people along ethnic lines. In these societies populism promotes exclusion, reserving political participation for the native population, whereas 'others' might face a reduction of their minority or other rights, or may be prosecuted as 'the corrupt elite'.

Populist movements in Canada (David Laycock) have a more sophisticated approach whereby exclusion incorporates no explicit ethnic tone. It seems that the long tradition of multiculturalism in Canada has created a barrier 
against explicit voices of social and ethnic exclusion; however, these tones are indirectly part of the populist argumentation. In Canada, public discontent with the traditional representative democratic system provided grounds for the emergence and growth of the Reform Party. Growth was particularly notable in the 1980s. The party reached out to a growing audience: it relied on politically disaffected voters and fostered political participation by talking about the 'democratic deficit'. The Reform Party attracted and bridged heterogeneous groups in society (the white middle class, working class, urban workers, farmers, small businesses), favoring 'ordinary working people' in the redesign of the redistribution system of the welfare state. The populist appeal of the Reform party was significant: it had a positive effect on political activity. However, the Reform Party's moral argumentation questioned the institutions of the welfare state and channeled frustration toward the most vulnerable groups and social minorities. The Reform Party's agenda explicitly lacked racist content and avoided threatening minority rights while at the same time re-defining 'the people' and excluding a range of groups that sought after a more egalitarian redistribution of resources and an expansion of the welfare state. Despite the fact that the populism of the Reform Party opposed 'the elites' it also constantly opposed the protection and guarantee of groupdifferentiated rights. This harmed minorities (natives, women, homosexuals, lesbians). The politics of mining out the populist opposition between 'them' and 'us' lead to the erosion of pluralistic, inclusive politics.

The cases of less well-off societies, like Mexico, Peru and Venezuela in Latin America, illustrate the fact that populism may take the inclusive meaning of people, thereby targeting vast numbers of socially and economically excluded groups. Alberto Fujimori's splendid rise in Peru is the most exciting illustration of how a wider electorate is gained by mobilizing marginalized groups. Fujimori was considered to be an outsider in politics when in 1990 he won the presidential election, sweeping away his adversary, the writer Mario Vargas Llosa. Fujimori was a mathematics teacher and university rector (of Japanese descent) and had no previous experience in public administration or politics. The authors (Steven Levitsky, James Loxton) refer to a triple crisis that paved the way to his success: economic collapse (with recession and hyperinflation), political unrest and guerilla fights, and a crisis of political representation. Public disaffection with politics and especially political parties fed Fujimori's credibility - a credibility that was even enhanced by his lack of ties to the establishment. Correspondingly, Fujimori relied on 'outsiders' and initially displaced the existing elite. As a second-generation migrant with a working class background, Fujimori addressed socio-economically marginalized groups as the 'man of the people'. He reached those working 
in the informal sector in villages, towns and cities. The campaign stressed Fujimori's own lines of descent, and those of his vice-presidents Máximo San Roman ('mestizo') and Carlos García (who has African roots). Ethnicity thus played an important role in the election campaign, and contrasted with the background of the 'white' Vargas Llosa who taught in European Universities and had strong ties with the economic-political elite. However, as a president Fujimori soon had to rely on the expertise of his adversaries to combat economic and security crises. Finally, he organized a coup d'etat to destroy the democratic institutional setup that had lead to the establishment of a competitive authoritarian political system.

The examples above illustrate cases of populism in opposition that gave rise to ruling power. It can be generally claimed that populist leaders gain their strength through popular demand. However, the higher positions they reach, the less they are capable of implementing their populist promises. Reasons for this include a lack of relevant knowledge about institutions (like cooperation, bargaining and negotiation, as in Venezuela, Peru and Slovakia), and/or the missing expertise to lead once elected (Austria) and legitimacy crises (Mexico).

How populism operates on a subnational level is illustrated in the cases of Mexico (Kathleen Bruhn) and Austria (Franz Fallend). The mayor of the huge Mexico City, Andrés Manuel López Obrador, in his fight against poverty, implemented inclusive policy measures in support of socially and economically marginalized groups. However, after losing the presidential elections he attacked public trust in democratic institutions through his nation-wide populist activities that appealed to the 'power of the people'.

The example of Jörg Haider is used to demonstrate the effects of populism in government on a provincial level. Populism might become a threat if firmly established institutions in a national government in a consolidated democracy are thought to be slowing down the populist machinery (this is in contrast to the examples drawn from Latin-America).

Reactions to the challenge of populism range from conflicts to cooperation. The illustrations vary: at one extreme stands the case of Venezuela, and on the other Austria with FPÖ-BZÖ as an example of successful cooperation. Based on these cases the editors define strategies of isolation, confrontation, adaptation and socialization as responses to growing populism that claims power. In Venezula (Kenneth M. Roberts) it was the former establishment that took action to precipitate the dismissal of Hugo Chavez's government. The (former) elite firstly attacked with extra-institutional tools: a military coup (2002); and later, by backing a strike at the national oil company (20023). Previously, Chavizmo had effectively taken control over the executive, 
legislative, and judicial branches of government and systematically dissolved democratic checks. The strategy of confrontation combined with populism proved to have elements of moralizing (more on this later).

In contrast, adaptation allows for populism to become legitimised, and the corrective effects of democracy to occur. The ÖVP and FPÖ coalition in Austria equally shared the key elective offices. Finally, FPÖ dissolved, leaving behind enhanced civic participation in political affairs as a positive effect. As we learn from this case, the fine-tuning of the strategy involved socialization,: the radical wing of the FPÖ dropped out of governance, while the moderate wing remained in the parliament in the shape of a new party.

The Belgian case of cordon sanitaire (Sarah L. de Lange, Tjitske Akkerman) illuminates a strategy of effective isolation. The VB (Flemish Interest) is the most successful populist party in Belgium, spectacularly growing from the 1980s onwards. Despite gaining a large number of votes and appealing to a large electorate, VB faced a cordon sanitaire, erected by the established parties to isolate government work from its ideology. VB was excluded from cooperation in the electoral, parliamentery and executive arena by the established parties, and its policy proposals were ignored. In response, the scope of political alternatives narrowed in the field of policies supported by $\mathrm{VB}$, especially in respect to migration and integration. The rise and growth of populist parties (especially VB) carries an important message from voters about the need to increase the receptivity of established parties in the electoral arena (it is worth noting that in Belgium political participation is mandatory and voting is a must; voters cannot abstain without being sanctioned. The number of votes, therefore, is not a suitable indicator of electoral choices. Results and protest votes should be interpreted based on these considerations). Critics of cordon sanitaire find the exclusion of a political force supported by voters based on moral argumentation somewhat problematic as it avoids the need for open discourse and problem solving.

In searching for a resolution to issues ignored by the establishment through the 'voice of the people', populism in opposition plays a positive role. It might act as a corrective to the quality of democracy by articulating the arguments and needs of groups that feel that representation is lacking. What we further learn from the case studies is that the corrective effect of populism in opposition is strongest if the ruling parties are receptive to the critical voice, and ready to implement changes.

The final chapter of the volume sums up the findings of the case studies. The analysis offers further valuable findings, apart from verifying the hypotheses. The minimum definitions and the set of hypotheses prove useful in an effective comparison that brings to light some determinants 
concerning the relationship of democracy and populism. The evaluation draws on highlights from the various contexts, providing a deeper insight into the phenomena under examination. The volume elucidates the differences in social, geographical and political contexts, but it does not analyse more deeply, or supply pointers for further investigation into this topic. Democracy is illustrated in a range of shapes, varying along different social, economic, and historical contexts. A comparison of these differences in the light of the applied framework elaborated by the authors would serve as an interesting path to follow. An investigation into the interaction of discourse, political forces and populist movements that are gaining growth in democracies more than twenty years after the transition in Central Eastern Europe - including Hungary - would be valuable components of a broader study that draws on the framework elaborated in this volume. 